\title{
INTERACTIVE COMMUNICATION WITH EDMODO IN EFL CLASSROOM
}

\author{
Yuliana Ningsih \\ yuliananingsih@politala.ac.id \\ Politeknik Negeri Tanah laut, Indonesia \\ Wan Yuliyanti \\ wanyuliyanti@politala.ac.id \\ Politeknik Negeri Tanah laut, Indonesia
}

\begin{abstract}
Virtual learning is very much important in the 21 st century in increasing interest in communicating in EFL classrooms. Edmodo is one of the media used for virtual learning. This research primarily aimed at describing interactive communication and students' perspective of the online media "Edmodo" as a means of learning the EFL Classroom. The method used is qualitative methods with data collection techniques with documentation techniques, and observation techniques. Students' perspective were collected by interviews. Besides that advantages of Edmodo and description classroom activities observed. The results of the analysis showed that Edmodo can be used as an effective learning medium. Edmodo, as a learning tool, can also be an easier introduction to students so that English knowledge be interested to communicate globally. Moreover, it revealed that using Edmodo had positive perspective from students towards interactive communication.
\end{abstract}

Keywords: virtual learning; Edmodo, interactive communication, EFL classroom

\section{INTRODUCTION}

The process of teaching and interactive. Some lecturers in Indonesia to learning English as a Foreign Language (EFL) teaching and learning process will be engaged teachers and students in various cases involving L1 use. This paper is keen to describe happening in the EFL classroom in particularly virtual learning, Edmodo. To some extent, it is believed that learning medium is such a help for both teachers and students in achieving the learning target and make the class take an account of the impact of the advantages of using virtual learning environments in the field of education and student learning.

Learning English through Edmodo represents a novel approach for some students whose preconceived notion of learning English based on their past learning experiences. Learning media constitutes something that can deliver the 
message, stimulate thought, feeling and will encourage the learning process. (Ramdhani \& Muhammadiyah, 2015)

Learning media can also make the learning process more varied, innovative so that it can increase student activity and creativity so that student learning achievement increases. One of these media is Edmodo as a virtual learning medium that is becoming a contemporary learning medium. Students can do this by accessing learning through the courageous media they have and are more interested in, one of which is that Edmodo can be applied in the classroom. In this way, students can communicate through Virtual Edmodo learning media.

Edmodo, an online learning environment is an interactive process where the student is assisted by others (teachers or peers) to acquire knowledge or skill that cannot be acquired without assistance at that point in time. Through Edmodo, educators and students can share notes, links and documents. Educators also have the ability to send alerts, events, and tasks for students and may decide to send something in a timeline that can be viewed by the public. In addition, Edmodo as online learning can benefit the students by promoting their self-regulated learning in a number of ways. Having access to language-related resources and tools available through Edmodo, the learners can choose and work with materials in line with their preferences and goals at any time and from any places. (Gay \& Sofyan, 2017).

By using Edmodo as the extension of the face-to-face interaction, it is expected that students can improve their English proficiency in a provided length of time, since it will increase the contact hours among students and teachers and facilitate peer feedback among students, which may create a productive learning environment for them, (Dewi, 2014 in Sumarno \& Tatiek, 2018). It arises from the idea that the focus of cognitive change of an individual is created the individual mindset after the intervention of this technology tool. Students are actively involved in preparing for their classroom lessons, and a sense of excitement for learning builds among themselves and the teacher during this early stage of the unit (Dobler, 2012 in Sumarno \& Tatiek, 2018).

The single greatest trend, and the one that is shaping all others, is the increasing use of other models of interactive communication on the Web. (Deborah: 2003). Kristine L. Fitch, Robert E. Sanders (2004) also explained that 
Language and Social Interaction is an interdisciplinary approach to studying the everyday practices and details that make up the complexities multifunctionality of human communication.

\section{METHODS}

In this study, the researchers chose the type of qualitative research, so the data obtained had to be deep, clear and specific. Qualitative content analysis is an approach to analysis that focusses on interpreting and describing, meaningfully, the topics and themes that are evident in the contents of communications when framed against the research objectives of the study. (Williamson, et all: 2018).

Qualitative data were analyzed by

\section{RESULTS AND DISCUSSION}

\section{Students' Perspective towards Edmodo in EFL Classroom}

Teacher and During the teaching and learning process, students were found to employ Edmodo intensively. Based on the occurrence, researchers chose to take the sample of students to conduct the further interview. During the interview, researchers asked questions related to the functions of Edmodo by students
Form the explanation above, this study describes students' perspective and interactive communication of the online media "Edmodo" as a means of learning the EFL Classroom.

students' scale reports, interviews and survey (with both open-ended and closedended questions). The validity of the research data was confirmed through data triangulation. 133 Students on the first semester and third semester at Agroindustry and also 49 students at Automotive Technology departments were asked to participate in the study. This study took place in Politeknik Negeri Tanah Laut (POLITALA).

conducted during the teaching and learning process. Students also expressed their perspective on the use of Edmodo in the classroom and

Students' view on Edmodo use in the classroom is also advantageous because it serves many functions to help them encounter the obstacle during the virtual learning process. The response below: 
"Learning through Edmodo is able to use English because English is a second language, so take advantage of Edmodo in learning English"

Based on the above extract, students showed their tendency to choose Edmodo during the virtual teaching and learning process. The lecturer was expected to deliver material in Edmodo, they considered that learning in this application sometimes are needed because it is easier. This proves that Edmodo is viewed as a beneficial side in a classroom setting.

\section{The Function of Edmodo for Students in EFL classroom}

Besides the supportive side of students towards Edmodo in EFL the classroom, Edmodo must have been views based on its functions. In general, the function of the Edmodo platform is to help education activists, be it teachers, students, lecturers, and even students. The functions of this platform are quite a lot, starting from being a social media for students and teachers, a place for learning, a place to do a material evaluation, and much more. The most interesting function of the Edmodo platform is that it helps teachers to share experiences through the Edmodo Community. This is stated as follows:

"Edmodo makes my learning more effective because the files and videos are very posted help to understand the lesson"

"Using Edmodo, I can access materials at any time and review them accordingly needs"

"Edmodo supports me to complete multiple tasks online, for example,

students can easily upload files and submit assignments, provide feedback

go back and communicate with peers and lecturers comfortably."

"I can communicate with the lecturer privately or openly"

"I like to submit assignments online

with Edmodo"

\section{"I like the folder / library in edmodo"}

It proved that Edmodo contributes to effective learning and makes it more motivating and interesting to learn, it can be conducted anytime and anywhere 
outside the classroom. Although sometimes in Edmodo comments there are some grammatical errors, It's understandable by the lecturers. The courage to express ideas in English proved that students think and tried to express and write these ideas in English. Its time and more learning so that students can use English properly and correctly.

Based on students' positive responses, Edmodo is considered an effective learning media that helps improve student learning because it increases student motivation, flexibility, and participation in online learning activities. Besides, some aspects of the implementation of Edmodo in the classroom need to better prepare students for the learning atmosphere in the blended class. Learning using Edmodo media is believed to have succeeded in making interested English learning and interactive for students and making the classroom more interesting.

E-learning is expected to reduce obstacles in learning because teaching and learning activities are no longer limited by distance and time. Students and lecturers no longer need to do faceto-face learning; however, interactions can be done through E-learning applications.

Edmodo based e-learning media can be used as an alternative in the learning process because it makes it easy for teachers to conduct teaching, interact with students, monitor student activity in groups, and do an evaluation.

Edmodo is used as an e-learning application because of its easy use; everyone accustomed to using social media such as Facebook can use Edmodo. Someone who is used to using Facebook, generally only one time following a short training in using Edmodo, will undoubtedly be able to operate it properly.

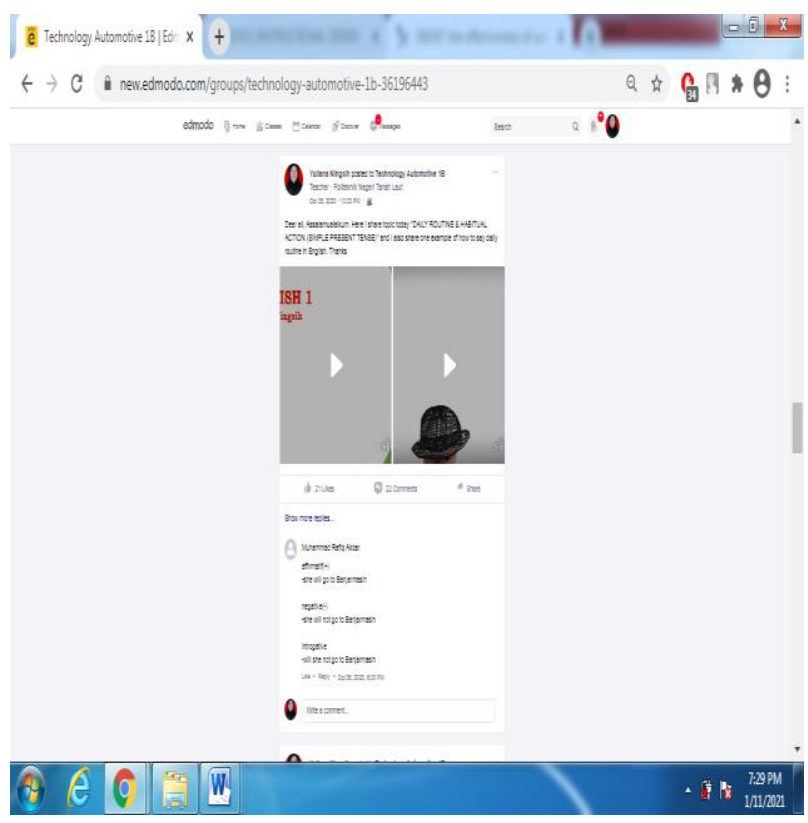

Figure 1. Students' Interactive Communication 1 


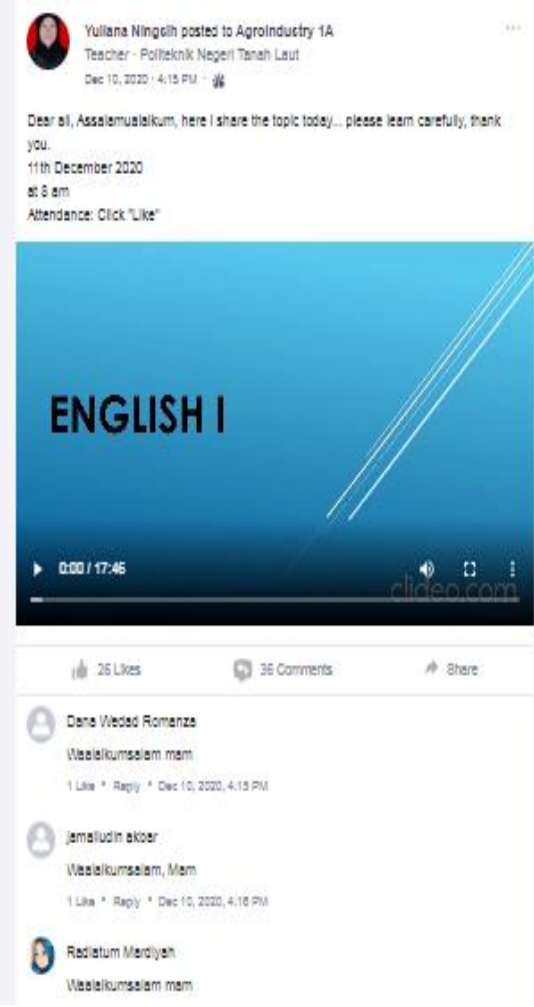

Figure 2. Students' Interactive Communication 2

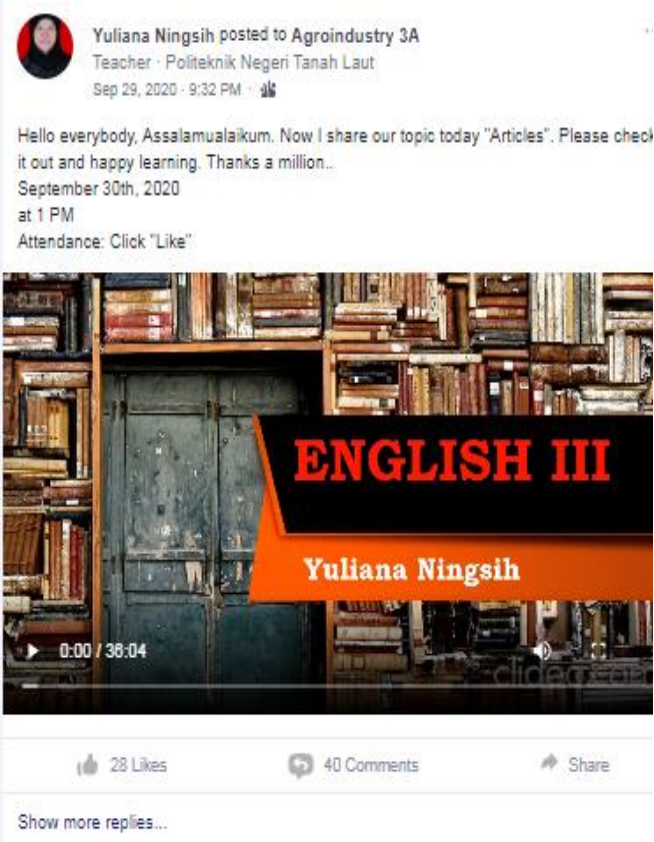

Figure 3. Students' Interactive Communication 3

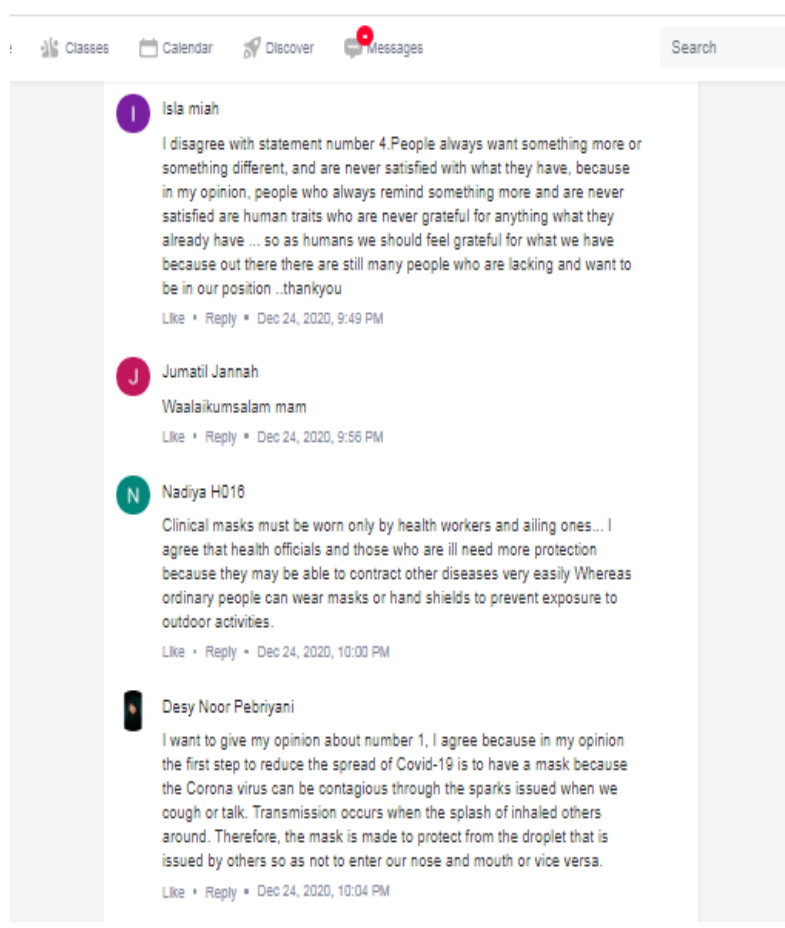

Figure 4. Students' Interactive Communication 4

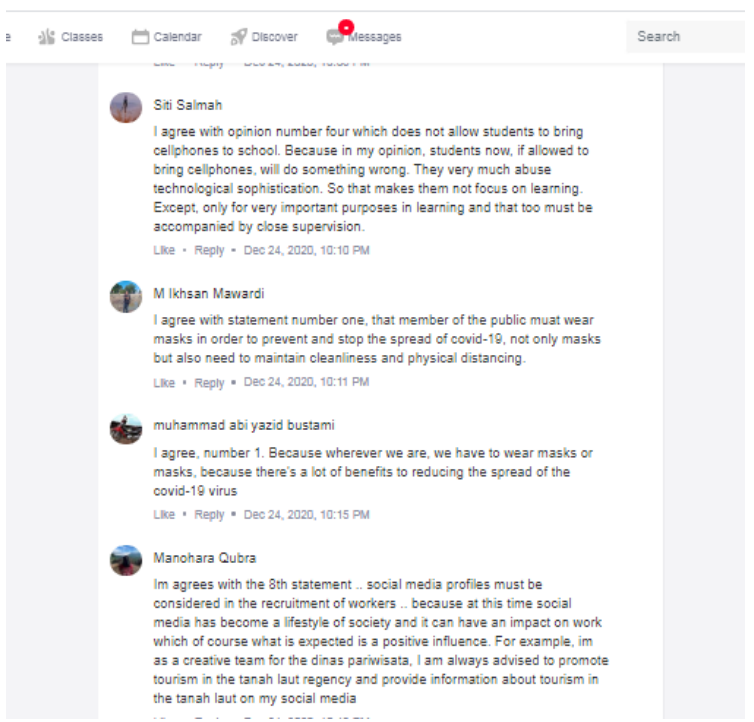

Figure 1. Students' Interactive Communication 5

From the observation of the virtual learning "Edmodo" above, it revealed that

Journal of English Education Vol. 6 No. 2, December 2020

http://journal.upp.ac.id/index.php/JEE 
learning in Edmodo can build interactive communication, varied, and learning students were active to use their English because the lecturer pushes them to use

\section{CONCLUSION}

Students have a positive perspective of Edmodo to give the most statements regarding ease on Edmodo's technical
English in writing comments, message and also when they had a presentation or speaking in the class.

aspects, and interactive communication can be conducted effectively.

\section{REFERENCES}

Deborah Bayles Kalman, in Encyclopedia of Information Systems, 2003

Dewi, F. (2014).EDMODO: A Social Learning Platform for Blended Learning Class in Higher Education. Research in Education Technology: Pedagogy and Technology Journal. SEAMEO-SEAMOLEC. Vol XI/No.2/2014

Dobler. (2012). Flattening Classroom Walls: Edmodo Takes Teaching and Learning across the Globe. www.reading.org

Gay, E., \& Sofyan, N. (2017). The Effectiveness Of Using Edmodo In Enhancing Students'outcomes In Advance Writing Course Of The Fifth Semester At FipUmmu. Journal of English Education, 2(1), 1-11.

Kristine L. Fitch, Robert E. Sanders. (2004). Handbook of Language and Social Interaction (Routledge Communication Series). Psychology Press

Ramdhani, M. A., \& Muhammadiyah, H. (2015). The criteria of learning media selection for character education in higher education.

Sumarno, W. K., \& Tatik, T. (2018). Integrating Edmodo-based Digital Portfolio With Efl Writing Instruction: Exploring The Students' Perceptions. Journal of English Education, 3(2), 100-106.

Williamson, et all (2018). Research Methods $\|$ Qualitative data analysis. 10.1016/B978-0-08102220-7.00019-4 